\title{
La Chanson de Walther («Waltharii poesis»), Texte présenté, traduit et annoté par Sophie Albert, Silvère Menegaldo, Francine Mora
}

\section{G. Matteo Roccati}

\section{(2) OpenEdition}

\section{Journals}

Édition électronique

URL : http://journals.openedition.org/studifrancesi/3633

DOI : 10.4000/studifrancesi.3633

ISSN : 2421-5856

Éditeur

Rosenberg \& Sellier

\section{Édition imprimée}

Date de publication : 1 décembre 2012

Pagination : 540

ISSN : 0039-2944

\section{Référence électronique}

G. Matteo Roccati, «La Chanson de Walther («Waltharii poesis»), Texte présenté, traduit et annoté par Sophie Albert, Silvère Menegaldo, Francine Mora », Studi Francesi [En ligne], 168 (LVI | III) | 2012, mis en ligne le 30 novembre 2015, consulté le 07 mars 2021. URL : http://journals.openedition.org/ studifrancesi/3633; DOI : https://doi.org/10.4000/studifrancesi.3633

Ce document a été généré automatiquement le 7 mars 2021.

\section{c)}

Studi Francesi è distribuita con Licenza Creative Commons Attribuzione - Non commerciale - Non opere derivate 4.0 Internazionale. 


\title{
La Chanson de Walther («Waltharii poesis»), Texte présenté, traduit et annoté par Sophie Albert, Silvère Menegaldo, Francine Mora
}

\author{
G. Matteo Roccati
}

\section{RÉFÉRENCE}

La Chanson de Walther («Waltharii poesis»), Texte présenté, traduit et annoté par Sophie ALBERT, Silvère MENEGALDO, Francine MORA, Grenoble, Université Stendhal, ELLUG, 2008 («Moyen âge européen»), pp. 168.

L'introduction présente le texte, «épopée carolingienne atypique» en hexamètres dactyliques, le cadre historique du récit et sa dimension germanique, ainsi que les références, au moins en partie ludiques, à Virgile, Stace et Prudence. Elle passe ensuite en revue la tradition manuscrite et les hypothèses qui ont été émises au sujet de la datation et de l'auteur: aucune ne s'est imposée dans la critique, même si la tendance actuelle pencherait plutôt pour une composition «précoce» dans l'entourage des empereurs et dans le cadre de la renaissance carolingienne. La traduction en prose, située en regard, s'efforce de rendre les effets stylistiques du texte et est accompagnée de notes en bas de page. Complètent le volume la chronologie, l'index des noms propres (personnages et lieux) et la bibliographie (pp. 153-165). 